\title{
Notes on the ecology, conservation and taxonomic status of Hylorchilus wrens
}

\author{
PHILIP W. ATKINSON, MARK J. WHITTINGHAM, HECTOR GOMEZ DE \\ SILVA GARZA, ADAM M. KENT and RUTH T. MAIER
}

\section{Summary}

Fieldwork conducted in Veracruz and Chiapas, Mexico, between July and December 1991 indicates that the genus Hylorchilus merits retention and that the two forms, $H$. (sumichrasti) sumichrasti and $H$. (s.) navai, are good species, based chiefly on this study's discovery of their very different voices. Both are, however, ground-level feeders on invertebrates gleaned from limestone outcrops under closed-canopy forest, and both are at risk from habitat loss. Despite the very restricted range of $H$. navai and threats to its habitat the population is partially protected and so it is recommended it be allocated IUCN status "Rare", while $H$. sumichrasti merits the existing classification "Vulnerable/ Rare".

Los trabajos de campo realizados en Veracruz y Chiapas, México, entre Julio y Diciembre de 1991 indican que el género Hylorchilus merece ser mantenido, y que las dos formas, $H$. (sumichrasti) sumichrasti y $H$. (s.) navai, son especies válidas, en base a las diferencias de voz descubiertas en este estudio. Ambas especies se alimentan a nivel del suelo, a base de invertebrados que capturan sobre rocas calizas en áreas de selva cerrada, y ambas están amenazadas por la pérdida de su hábitat. A pesar de que $H$. navai tiene un área de distribución muy pequeña y de que su hábitat está amenazado, la población está parcialmente protegida y por lo tanto se recomienda que se le considere en la categoría de amenaza "Rara" de la UICN, mientras que $H$. sumichrasti debe continuar como "Vulnerable/Rara".

\section{Introduction}

The genus Hylorchilus comprises two forms of wren which at present are lumped together in one species $H$. sumichrasti, Sumichrast's Wren, endemic to southern Mexico. The species was described by J. N. Lawrence in 1871 from Veracruz under the name Catherpes sumichrasti. Later, the genus Hylorchilus was established for it (Nelson 1897). In Chiapas in 1970, Crossin and Ely (1973) discovered a second form of Hylorchilus which they viewed as a race and named $H$. sumichrasti navai. Phillips (1986) raised the possibility that the two forms might be separate species, basing his conclusions on the different morphological shapes of the two forms. However, owing to habitat destruction, he thought that this would never be proven. This was the first suggestion that two species may be involved. The two populations are treated as distinct subspecies in the current literature, but even so the total population of Hylorchilus (i.e. H. sumichrasti and H. navai) is treated as threatened in the Red Data Book for the Americas (Collar et al. 
1992), which identified and mapped twelve sites in all, nine for nominate sumichrasti in Veracruz and adjacent northernmost Oaxaca and three for navai in Chiapas and easternmost Veracruz (Uxpanapa) (see Figure 1).

In the last decade, records of Hylorchilus come from only four areas (sites 2, 3,8 and 12 on the map in Collar et al. 1992) but it is likely to occur in more. $H$. sumichrasti has been recorded from Amatlán $\left(18^{\circ} 50^{\prime} \mathrm{N} 96^{\circ} 55^{\prime} \mathrm{W}\right)$, a site found by S. N. G. Howell and P. Pyle, and nearby at the site described by Hardy and Delaney (1987), which is $15 \mathrm{~km}$ south of Córdoba, both being in Veracruz. $H$. navai has only recently been recorded from two areas, El Ocote $\left(17^{\circ} \mathrm{Or}\right.$ ' $\mathrm{N}$ $93^{\circ} 47^{\prime} \mathrm{W}$ ) in Chiapas, and in several localities in the Uxpanapa region in Veraruz by $K$. Collins and $T$. Wendt. Birds have not been seen at the type-locality since their discovery in 1970-1971, and may well be extinct in that area. In Reserva El Ocote, the birds were discovered near the mouth of the Rio La Venta in September 1990 by R. Dominguez and P. J. Bubb of the Mexican environmental organization ECOSFERA; this is the only known population in a protected area.

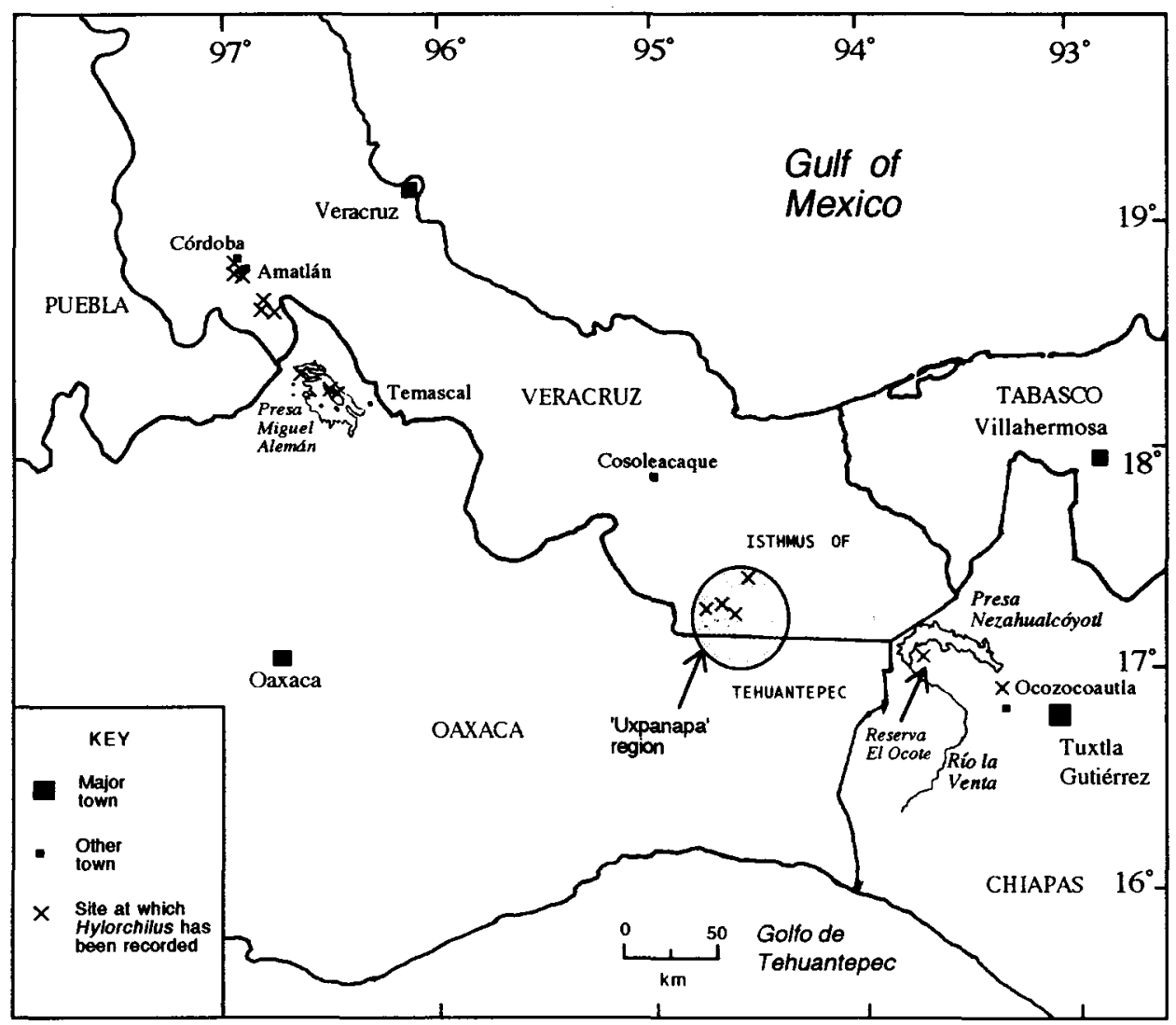

Figure 1. Map of Mexico showing all known localities of Hylorchilus. Data are from Collar et al. (1992) with additional sites in the Uxpanapa region identified by H.G.S.G., S. N. G. Howell, K. Collins and T. Wendt. 
During July to September 1991 four areas (sites 2, 10, 11 and 12 on the map in Collar et al. 1992) where Hylorchilus has been previously recorded were visited. We found the birds at two, El Ocote in Chiapas (25 July-5 August) and the well known site for $H$. sumichrasti $2 \mathrm{~km}$ from Amatlán (6-8 September). We also visited the type-locality for $H$. navai, $26 \mathrm{~km}$ north-north-west of Ocozocoautla by road between 13 and 18 August, and the Reserva Educativa Laguna Bélgica, $3 \mathrm{~km}$ to the south, but failed to find the wren at these sites. A patch of forest near Temascal was explored, as birds had formerly been present in this area (Collar et al. 1992), but we were unable to locate any. A fifth site, the island San Miguel Soyaltepec near Presidio $\left(18^{\circ} 41^{\prime} \mathrm{N} 96^{\circ} 44^{\prime} \mathrm{W}\right)$, was circled by boat on 7 September. Apparently suitable forest remains on the upper slopes, despite clearance for agriculture on the lower slopes, though records from this site came before the area was flooded and the reservoir built. Between 31 December 1991 and early January 1992, one of us (H.G.S.G.) visited areas in the Uxpanapa region with S. N. G. Howell, acting on information given to Howell by K. Collins and T. Wendt who had previously discovered the birds there. Wrens were seen in two places just inside Veracruz, but none was seen at an apparently suitable site in adjacent Oaxaca.

\section{Taxonomic status}

\section{Validity of the genus Hylorchilus}

A single tailless specimen of $H$. sumichrasti was first described by J. N. Lawrence in 1871 and placed in the genus Catherpes. In 1894, two perfect specimens were collected and Nelson (1897) placed the species in a new genus, Hylorchilus. So it remained until Hardy and Delaney (1987) recommended that Hylorchilus be submerged in Catherpes, basing their recommendation on the supposed similarity of song, call and behaviour while singing of $H$. sumichrasti to Canyon Wren C. mexicanus. Sibley and Monroe (1990) accepted this argument although B. L. Monroe, Jr. (in litt. to S. N. G. Howell) now considers this an error and the forthcoming seventh edition of the AOU checklist maintains Hylorchilus.

The discovery of the song of $H$. navai, which is totally dissimilar to C. mexicanus, provides fresh evidence for the continued separation of the two genera. This is supported by long established morphological differences. Hylorchilus possesses an extremely short rounded tail with only ten rectrices, not twelve (Crossin and Ely 1973), and has relatively larger, more robust, tarsi and feet than the Canyon Wren. The shape of the wings and individual remiges of the two genera are very different, the short rounded wing of Hylorchilus having very different-shaped primaries from the long pointed wing of Catherpes (Figure 2). These adaptations point to different lifestyles between the two groups. Other anatomical differences are to be found in the descriptions of Ridgway (1904). Owing to the striking vocal and morphological differences between $H$. navai and wrens of the genus Catherpes we recommend that the two genera be kept separate. 


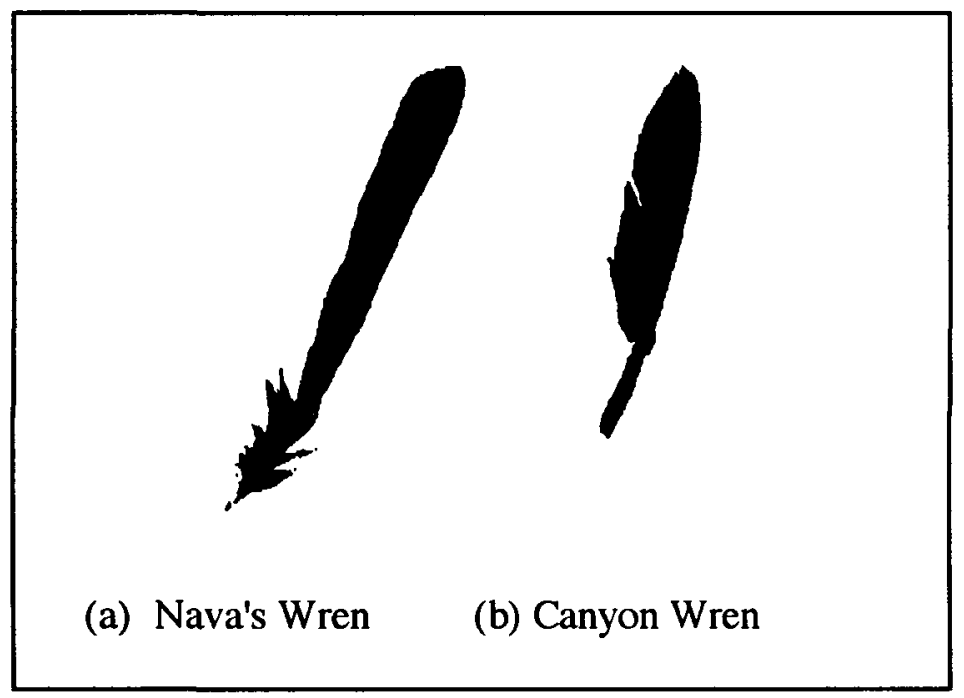

Figure 2. Feather shape of second outermost primary of Nava's Wren $H$. navai and Canyon Wren Catherpes mexicanus.

Morphological and plumage differences between the two forms of Hylorchilus

When specimens of Hylorchilus were obtained in the winter of 1970-1971 in Chiapas, they were viewed as a new subspecies owing to differences in their plumage, the throat and upper breast being whitish in navai, brownish in sumichrasti (Crossin and Ely 1973). Distinct black barring is found on the rectrices of navai compared with the weakly barred tail of sumichrasti, which is too faint to be seen in the field. Crossin and Ely (1973) published measurements of the two forms. Although the number of specimens is limited, these data are useful. Navai shows a slightly shorter tail $(40.85 \mathrm{~mm}$ in navai, $42.45 \mathrm{~mm}$ in sumichrasti) but longer tarsus $(29.7 \mathrm{~mm}, 28.6 \mathrm{~mm})$, bill $(27.05 \mathrm{~mm}, 26.15 \mathrm{~mm})$ and male wing chord $(68.4 \mathrm{~mm}, 66.9 \mathrm{~mm})$. These suggest a slightly different-shaped bird, supporting Phillips (1986).

Vocal differences between the two forms of Hylorchilus

In El Ocote, we used playback of published tapes of sumichrasti to aid our fieldwork, as the song of navai was unknown. The calls were known to be different, Crossin and Ely (1973) describing navai's as a loud "peenk" and the published recording of sumichrast $i$ being a harsh high-pitched "we-ooo".

Near the mouth of the Río La Venta we found individuals of the form navai to be singing and obtained recordings (Figure 3). Expecting the song to be similar to that of sumichrasti, we were very surprised at the distinctiveness of navai's vocalizations. Once its song had been recorded it was used for playback purposes and produced a vigorous response by the birds countersinging. However, navai did not respond to any vocalizations of sumichrasti. Conversely, at Amatlán sumichrasti did not respond to recordings of navai but responded to recordings of sumichrasti by investigating the tape and countersinging. 

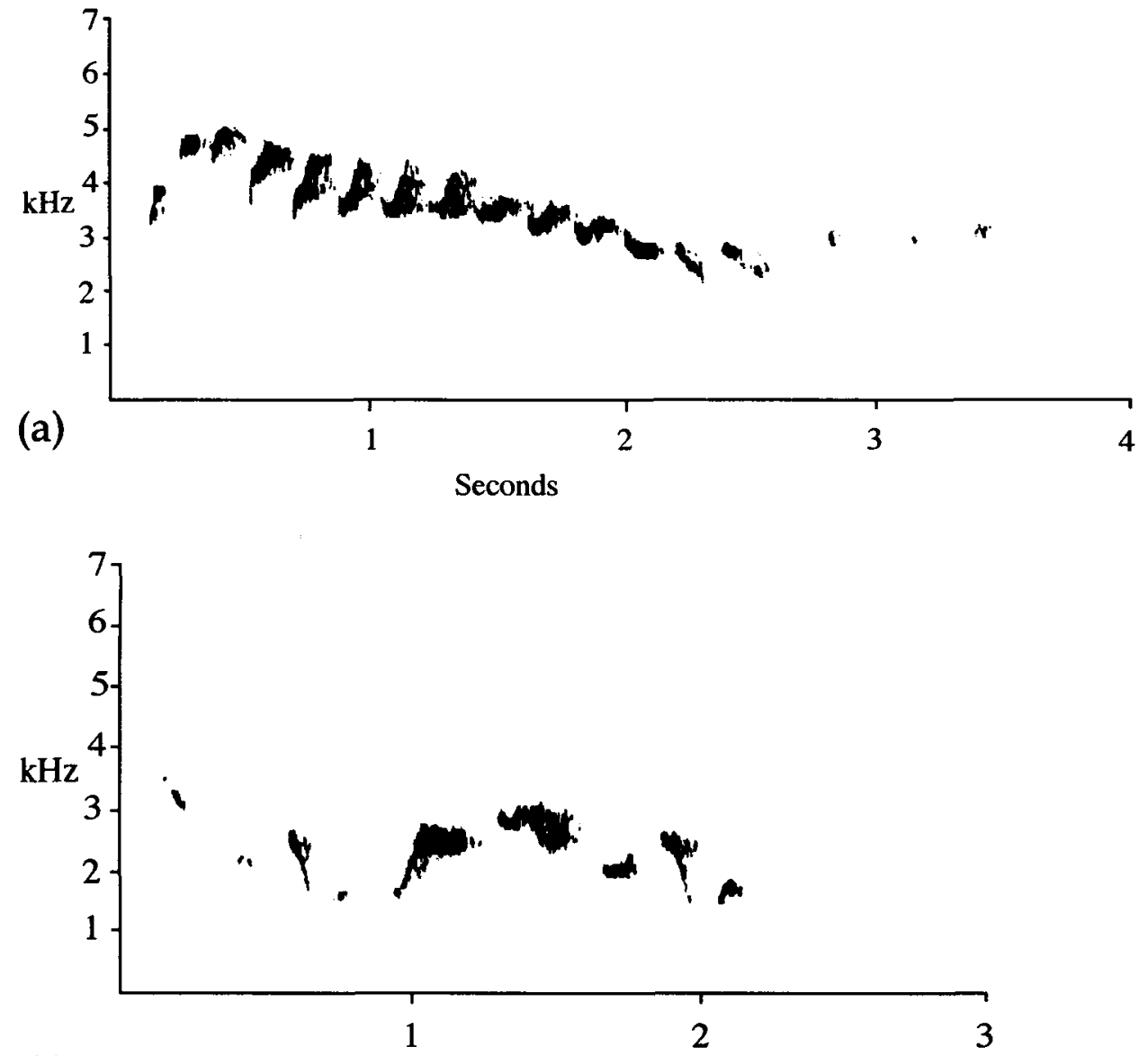

(b)

Seconds

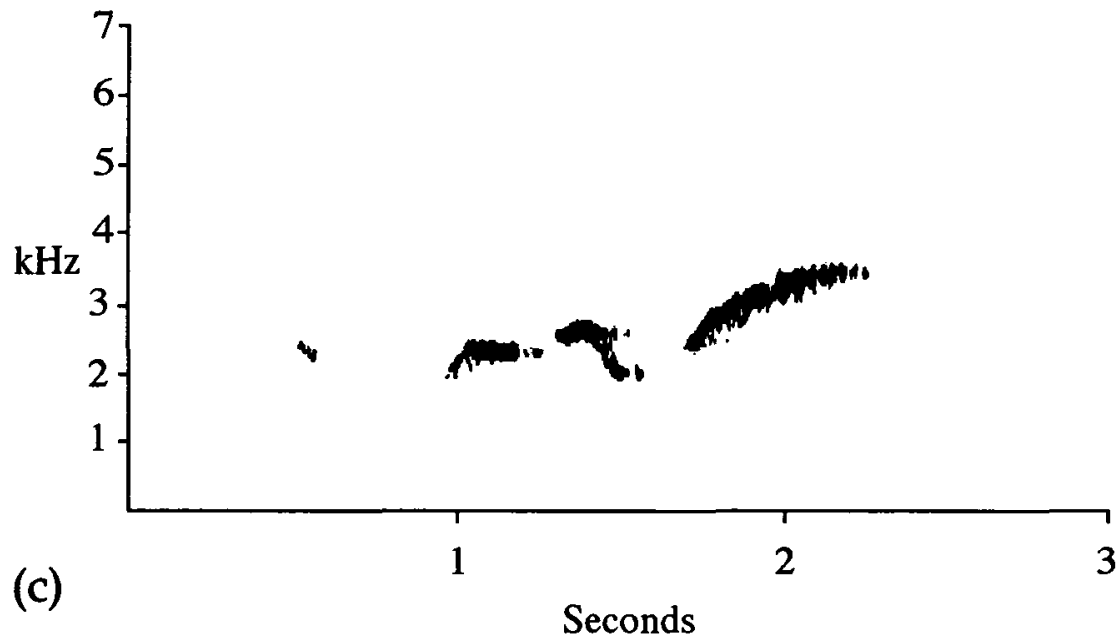

Figure 3. Sonagrams of the song of (a) Sumichrast's Wren H. sumichrasti (S. N. G. Howell), and two song variants of (b) and (c) Nava's Wren H. navai (A.M.K. and P.W.A.). 
The two populations are geographically isolated and sedentary (Figure 1). The difference in plumage is clear, and the lack of response from one form to the song of the other leads us to recommend that the two be given full specific status. We further recommend that they be known as Sumichrast's Wren Hylorchilus sumichrasti and Nava's Wren $H$. navai.

\section{Notes on the ecology and behaviour of Hylorchilus}

\section{Nava's Wren}

In El Ocote, $H$. navai was found to occur only in areas of shaded limestone outcrops covered with lowland evergreen primary forest. The forest had a closed canopy at a height of $15-20 \mathrm{~m}$ and the understorey was very sparse. The climate was hot and humid, rainfall being in the region of 2,000-2,500 $\mathrm{mm}$ per annum, with an average temperature of $24^{\circ} \mathrm{C}$ (García 1973). Limestone outcrops occurred throughout our study site, being situated in a steep-sided valley running off the Rio La Venta canyon. The size of outcrops varied from small boulders emerging from the soil to cliffs approximately $10 \mathrm{~m}$ tall running along the side of the valley.

Birds were usually recorded singly; only infrequently were two individuals heard at the same time. Most birds observed were perched on limestone outcrops, exceptions being singing individuals which occasionally moved to low vegetation. Most birds spent the majority of their time at ground level, hopping from rock to rock and foraging in small caves and crevices in the limestone. All individuals were reluctant to fly and flew only short distances, from rock to rock. Most were seemingly untroubled by our presence but were difficult to see while feeding owing to their skulking behaviour. We saw individuals feeding on most days in El Ocote. They foraged on the lichen-covered surface of the limestone and in the cracks and crevices of boulders, gleaning invertebrates. All individuals were seen in closed-canopy areas, with none being recorded in more open areas with seemingly suitable limestone crops.

Birds sang from rocks and from low vegetation at all times of day. When delivering the song they would stand up straight, throwing their heads back and depressing the tail. Each individual had its own unique song-type. When a song-type specific to one individual was played to a different bird it would respond by mimicking the other's voice. One individual had at least three song variants, a fact also noted in the Uxpanapa birds (S. N. G. Howell in litt.). Similarly, individuals of sumichrasti at Amatlán were found to have two, or possibly three, song-types including a short and long variety (S. N. G. Howell in litt.).

In El Ocote a fixed $2.3 \mathrm{~km}$ transect was walked twice daily between dawn and 11 hoo. Individual birds were recorded at approximately the same distances along the trail, indicating some degree of sedentary and territorial behaviour. Of the seven birds regularly encountered, four were often singing and the songs of two were recorded. The song was estimated to travel $82 \mathrm{~m}$ and this bandwidth has been used in calculations of densities. Transect data produced an average of 3.24 birds per kilometre of transect walked (range: 1.67-4.17) and 
gave a very rough density estimate of between 10.2 and 25.4 birds per $\mathrm{km}^{2}$, averaging 19.7 .

Crossin and Ely (1973) suggested a "quiet" post-breeding period to explain Crossin's lack of success in finding Nava's Wren in mid-August 1971, the species being abundant at the same site the following winter. Our results from El Ocote contradict those of Crossin and Ely, though we did not see any birds when we visited the type-locality in August 1991. However, in late September, only calling birds were noted in $\mathrm{El}$ Ocote (P. J. Bubb in litt.).

An individual of navai was mist-netted on 2 August (Figures 4 and 5) and was undergoing a complete body moult indicative of post-breeding. This would appear to indicate a breeding season similar to that of sumichrasti (between May and July: see below).

\section{Sumichrast's Wren}

H. sumichrasti was observed at Amatlán in September 1991. It occupied a similar niche to H. navai (ground-level feeding on limestone outcrops in closed-canopy lowland forest) but the habitat was secondary (overgrown coffee plantation) with the large shade-trees providing a dense forest-type habitat, although more open than in El Ocote, hence the ground vegetation was denser, with a canopy height of 23-30 m. Limestone outcropping was slightly less continuous than in El Ocote. The species was observed only a few hundred metres from the edge of the forest where a limestone quarry was situated. In February one of us (H.G.S.G.) visited the quarry and, although no birds were observed, the

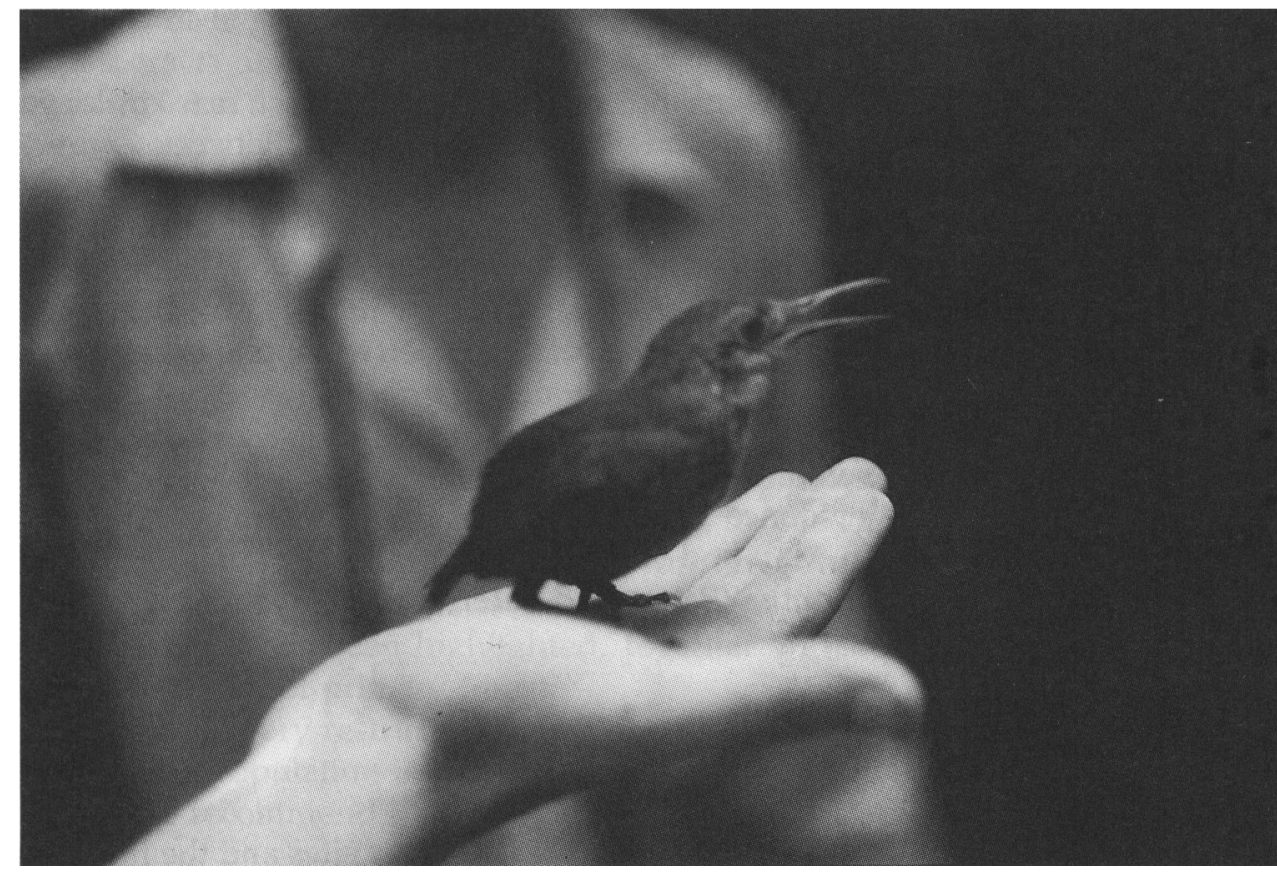

Figure 4. Photograph of Nava's Wren, trapped at El Ocote. 


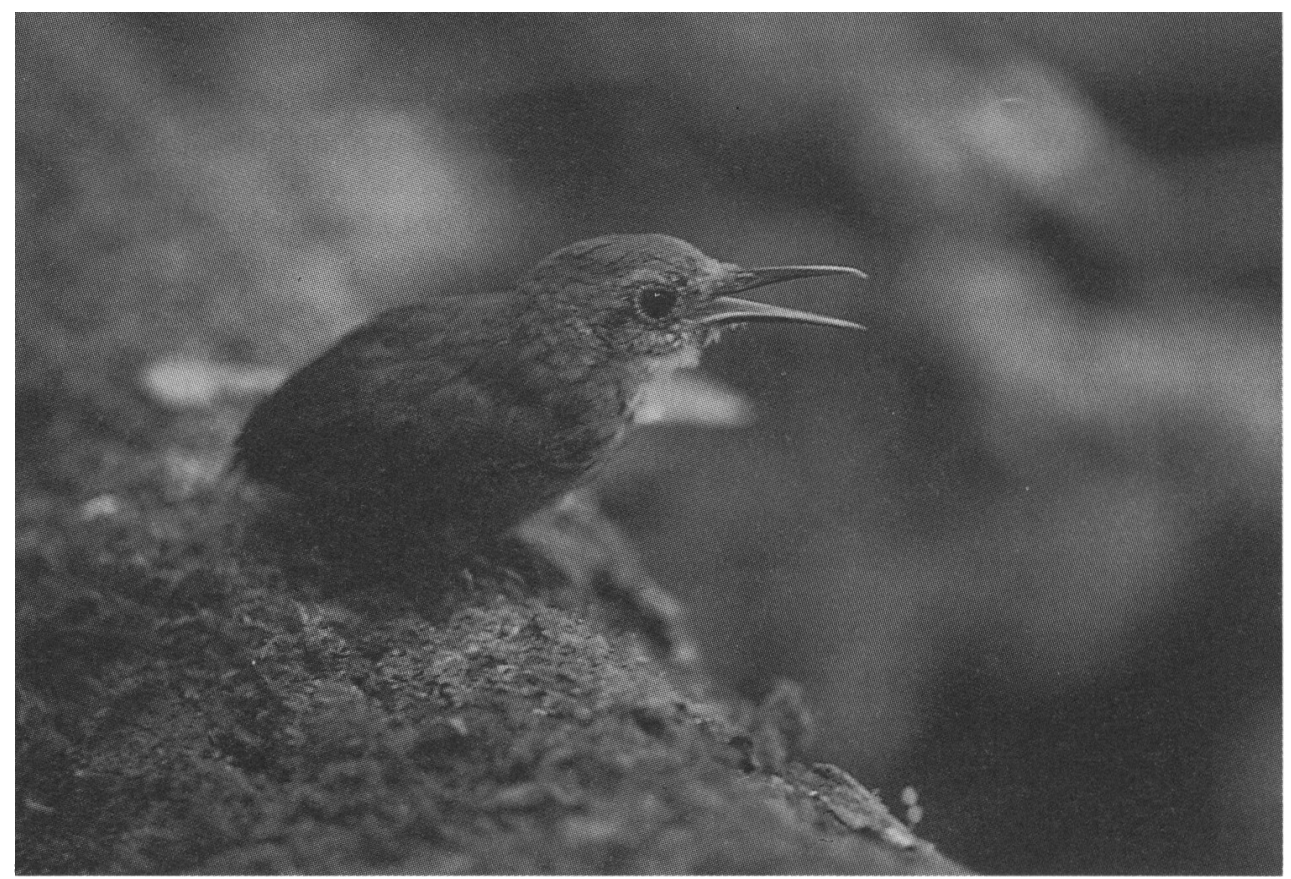

Figure 5. Nava's Wren at El Ocote.

workers at the quarry knew the wren well and reported having seen it in the immediate vicinity of their working area.

On five occasions between dawn and 11hoo a fixed transect, $1.6 \mathrm{~km}$ long, was walked through a section of secondary forest at Amatlán. Between 2.5 and 6.25 birds were recorded per kilometre of transect walked, giving an average density of 4.22 . Although the distance the call travelled was not estimated it appeared to be much the same as that of Nava's Wren in El Ocote. The numbers recorded per transect in both areas were similar.

The only difference noted in behaviour between the two species was when singing. Individuals of sumichrasti tended to sing in a more horizontal posture with the tail cocked, as opposed to the tail held depressed in navai (S. N. G. Howell in litt., H.G.S.G. pers. obs.).

Although we found no evidence to indicate breeding, previous data suggest a breeding season between May and July: nests and young of $H$. sumichrasti have been found in these months (Bangs and Peters 1927).

\section{The urgent need for conservation}

Nava's Wren

Recent records for Sumichrast's Wren come from very few sites and the number that has accumulated for Nava's since its discovery in 1973 remains very low. Both El Ocote and Amatlán are under threat from development, the former by 
a planned road and the latter by encroaching limestone quarrying operations and coffee plantations.

In south-eastern Veracruz, Nava's Wren is found in very small forest patches (generally less than $1 \mathrm{~km}^{2}$ ), where the presence of limestone outcropping has prevented the patch being used for rangeland. Twenty years ago the rainforest was continuous across the Isthmus of Tehuantepec, but now road-building and the ensuing settlement and cattle-ranching is claiming much of this area. Thus, much of the habitat in which Nava's Wren is found is being fragmented and soon only isolated patches of forest will hold this bird. Limestone outcropping is not continuous, so the population of Nava's Wren seems likely to have always been patchy within this large area of forest.

It is likely that Nava's Wren occurs in areas of suitable limestone habitat from El Ocote eastward to the Uxpanapa localities (see Figure 1). However, clearance of forest is proceeding in the Uxpanapa region, and the Reserva El Ocote is the only protected area in which Nava's Wren and indeed Hylorchilus occurs (Collar et al. 1992). Consequently, it is an area of vital importance for this species. The recent Ocozocoautla-Apic Pac road has opened up the surrounding areas to development for cultivation and threatened much suitable habitat. That the wren occurred here is undisputed as Crossin and Ely (1973) found it in a patch along the side of this road. It may still do so as the forest patch still exists. However, in August 1991 we spent a morning in the actual area they found the wren and three days in a patch of forest $3 \mathrm{~km}$ away, but failed to find it in either.

A proposal to build a road through the El Ocote Reserve has recently been rejected but only in as much as the road has been diverted. Any new roads in the area of El Ocote will lead to settlement along a line bisecting one of the largest tracts of undisturbed primary forest in southern Mexico. Although the birds do seem to be tolerant of some disturbance, habitat destruction will cause them eventually to disappear. Closed-canopy forest appears to be vital for this bird and the widespread forest clearance which will undoubtedly take place as the road is completed will destroy much of the remaining suitable area. Cattle-ranching is also a major factor in habitat clearance in the area and an indirect threat to both species. The limestone outcrops on which the wrens depend are generally not suitable for ranching. However, as outcropping is patchy, ranching will destroy surrounding areas that are suitable and leave these outcrops isolated. This has important implications in the future survival of both species as, (predictably) being poor dispersers, the patches would have to be of an appropriate size and habitat type for the species' long-term survival. An examination of the impact of cattle-ranching on forest retreat in the region where Nava's Wren occurs is needed, especially now that the vulnerability of this species has been highlighted, together with research to determine the importance to it of primary forest.

Despite the very restricted distribution of Nava's Wren and the threats to its habitat, the population is partly protected in the form of the El Ocote Reserve and so we recommend it be given the IUCN classification "Rare". 


\section{Sumichrast's Wren}

Sumichrast's Wren is apparently able to survive in a man-altered habitat, as it is currently to be found in shaded coffee plantations at Amatlán. We also saw birds near where quarrying operations were occurring, so it seems able to tolerate some amount of disturbance. More research is needed especially at the Amatlán site to assess the effects disturbance has on the population by looking at densities near to and far from the quarrying operations. Basic ecological studies are needed to determine its overall requirements and tolerance.

Sumichrast's Wren has a very restricted distribution and the habitat is under similar threats to those of Nava's Wren (Collar et al. 1992). However, although the species is known from a larger number of sites than Nava's Wren the population is wholly unprotected and so we concur with Collar et al. who describe it as "Vulnerable/Rare".

\section{Acknowledgements}

In the U.K. Melanie Heath, Adrian Long and David Wege of ICBP provided much help. In Mexico we would like to thank all those at ECOSFERA and PRONATURA who made us feel welcome, especially Romeo Domínguez and Ignacio J. March who gave unstintingly of their time. We are grateful to them for help with transport and their encouragement in developing the wren project. K. Collins, T. Wendt and A. Zimmerman helped with information relating to the Uxpanapa site. Special mention must be made of Philip Bubb, who first suggested the project and who helped us through the initial stages. We are indebted to Steve Howell for providing copies of his recordings of $H$. sumichrasti and to Richard Ranft of the British Library of Wildlife Sounds who very kindly produced sonagrams for us. Steve Howell, David Wege and Ted Parker very kindly provided comments on drafts of this paper. B. Heredia kindly prepared the Spanish summary. Many thanks to the University of East Anglia Travel Award Scheme, which provided grants for P.W.A., M.J.W. and R.T.M.

\section{References}

AOU (in prep.) Checklist of the birds of Mexico. Seventh edition. Auk. Supplement no. 37 .

Bangs, O. and Peters, J. L. (1927) Birds from the rain forest region of Veracruz. Bull. Mus. Comp. Zool. 67: 471-487.

Collar, N. J., Gonzaga, L. P., Krabbe, N., Madroño Nieto, A., Naranjo, L. G., Parker, T. A. and Wege, D. C. (1992) Threatened birds of the Americas: the ICBP/IUCN Red Data Book. Cambridge, U.K.: International Council for Bird Preservation.

Crossin, R. S. and Ely, C. A. (1973) A new race of Sumichrast's Wren from Chiapas, Mexico. Condor 75: 137-139.

Garcia, E. (1973) Modificaciones al sistema de clasificación de Koppen. UNAM, Mexico: Instituto de Geografía.

Hardy, J. W. and Delaney, D. J. (1987) The vocalizations of the Slender-billed Wren (Hylorchilus sumichrasti): who are its close relatives? Auk 104: 528-530.

Nelson, E. W. (1897) Preliminary descriptions of new birds from Mexico and Guatemala in the collection of the United States Department of Agriculture. Auk 14: 42-76.

Phillips, A. R. (1986) The known birds of North and Middle America, part 1. Denver, Colorado: Allan R. Phillips. 
Ridgway, R. (1904) The birds of North and Middle America. Bull. U.S. Natn. Mus. 50(3). Sibley, C. G. and Monroe, B. L. (1990) Distribution and taxonomy of the birds of the world. New Haven: Yale University Press.

PHILIP W. ATKINSON

Greylands, Rue des Grons, St Martin, Guernsey, Channel Islands.

MARK J. WHITTINGHAM

107 Tavistock Drive, Mapperley Park, Nottingham NG3 5BE, U.K.

HECTOR GOMEZ DE SILVA GARZA

Xola 314-E, o310o México DF, Mexico.

ADAM M. KENT

3513 NW 1oth Avenue, Gainesville, FL 32605, U.S.A.

RUTH T. MAIER

School of Environmental Sciences, University of East Anglia, Norwich NR4 7TJ, U.K. 